\title{
The urease enzymes of Campylobacter pylori and a related bacterium
}

\author{
R. L. FERRERO, S. L. HAZELL and A. LEE
}

School of Microbiology, University of New South Wales, Kensington (2033), NSW, Australia

\begin{abstract}
Summary. The urease enzyme of Campylobacter pylori was studied and compared with that of a related spiral-shaped bacterium, St 1, isolated from the rodent ileum. Both bacteria possessed constitutive urease enzymes with activities up to 20-70 times that of Proteus vulgaris. This activity was retained on SDS-polyacrylamide gels. A major catalytic subunit of mol. wt 300000 was located for all (six) strains of C. pylori subjected to SDS-PAGE whereas Stl had two active forms of mol. wts 140000 and 150000 . Western-blot analysis indicated the presence of anti-urease antibodies in the sera of patients with $C$. pylori-associated gastritis. The response to $C$. pylori urease was not strain-specific but no cross-reactivity was detected between the $C$. pylori enzyme and that of St 1 . The very high urease activity of these bacteria is likely to be important in colonisation of the host. Possession of glutamate dehydrogenase activity by both organisms suggests that one role of the urease may be to assimilate the available urea nitrogen. Modification of the local environment to facilitate long-term colonisation is another possible function. Protection from acid is unlikely to be a primary role as the natural habitat of the organism St 1 is the non-acid-secreting tissue of the small intestine.
\end{abstract}

\section{Introduction}

The enzyme urease (E.C.3.5.1.5.), originally isolated from jack beans (Sumner, 1926), catalyses the hydrolysis of urea to ammonia and carbon dioxide. Urease enzymes have since been isolated and purified from many species of bacteria, in which they play an important role in nitrogen metabolism. The ability to hydrolyse urea has several consequences for mammalian hosts colonised by urease-positive micro-organisms, including: regulation of transfer of endogenous urea across the rumen wall (Cheng and Wallace, 1979); an effect upon the nitrogen metabolism of ruminants (Wozny et al., 1977); production of urinary stones (Griffith and Musher, 1973); and contribution to the pathogenesis of pyelonephritis (Braude and Siemienski, 1960; Musher et al., 1975).

Campylobacter pylori, an organism which is an aetiological agent of active chronic gastritis and a possible contributor to peptic ulceration (Marshall and Warren, 1984; McNulty and Watson, 1984; Rollason et al., 1984), possesses an extremely high level of urease activity. Moreover this property provides a useful basis for the diagnosis of $C$. pylori-

Received 5 Oct. 1987; revised version accepted 25 Jan. 1988. associated gastritis by the detection of urease directly from gastric biopsy tissue (McNulty and Wise, 1985; Hazell et al., 1987). Hazell and Lee (1986) hypothesised that the high urease activity of $C$. pylori caused hydrogen ion back-diffusion in the gastric epithelium and that this was a predisposing factor in gastric ulcer formation. Others have proposed that, given the sensitivity to acid of $C$. pylori, a function of the urease may be to create an insulating neutral-to-alkaline blanket around the organism to protect it from the lethal effects of stomach acid (Goodwin et al., 1986).

An appreciation of the role of any given phenotypic property of an organism within its environmental niche may be enhanced by comparative studies of organisms that preferentially colonise similar environments. In this regard, comparisons between a urease-positive spiralshaped bacterium isolated from the ileal crypts of rodents (Lee and Phillips, 1978) and C. pylori may provide useful information. This rodent bacterium, $\mathrm{St} 1$, is an autochthonous member of the rodent gastrointestinal tract and, like C. pylori, is microaerophilic, possesses sheathed polar flagella and has adapted to a mucus environment.

The similarities between these spiral bacteria may permit comparisons of the effect of urease on 
mucosal colonisation in acid-secreting and nonacid-secreting environments. The first consideration in any such study is to ascertain the comparative levels of urease activity of each bacterial type and to determine whether the activity of the enzyme can be regulated by the presence of nitrogen or ammonia. Second, there is a need to isolate and purify the enzyme. This paper describes studies on the urease enzymes of $C$. pylori and Stl which are an essential pre-requisite to an investigation of the role of these enzymes in the colonisation of intestinal mucosae.

\section{Materials and methods}

\section{Bacterial strains}

C. pylori strains P2, P3, P16, P17, P21, 5298, G1, D1 and NCTC 11639 were clinical isolates. The culture of St1 was described previously (Lee and Phillips, 1978). Proteus vulgaris was provided by the Culture Collection of the School of Microbiology, University of New South Wales. Bacteria were grown on Blood Agar Base No. 2 (Oxoid) supplemented with lysed horse blood $5 \% \mathrm{v} / \mathrm{v}$ and amphotericin B (E. R. Squibb and Sons, Inc., Princeton, USA) $0.5 \% \mathrm{w} / \mathrm{v}$. Plates inoculated with $C$. pylori and St 1 were incubated at $37^{\circ} \mathrm{C}$ in a micro-aerophilic atmosphere for 3-4 days. $P$. vulgaris was grown on the same medium and incubated at $37^{\circ} \mathrm{C}$, aerobically for $18 \mathrm{~h}$.

\section{Urease assay}

Bacteria were washed from culture plates with freshly prepared saline, and the cells were centrifuged at 10000 $g$ for $3 \mathrm{~min}$. After resuspending in fresh saline, the optical density of the suspension was adjusted to a value of 1.0 at a wavelength of $600 \mathrm{~nm}$. Before the assay, cells were further diluted with an equal volume of saline.

Urease activity of whole bacteria was measured by a modification of the method of Kaltwasser and Schlegel (1966). The reagents used were obtained from the Urea/ Ammonia test system (Boehringer Mannheim GmbH, Mannheim, Germany). Reagents per $3 \mathrm{ml}$ quartz cuvette were: NADH $0.4 \mathrm{mg}$ and 2-oxoglutarate $2.2 \mathrm{mg}$ in $1.0 \mathrm{ml}$ of triethanolamine buffer $(p \mathrm{H} 8) ; 0 \cdot 1 \mathrm{ml}$ of a urea solution $(140 \mathrm{mg} / \mathrm{ml}) ; 20 \mu \mathrm{l}$ of glutamate dehydrogenase (c. 830 $\mathrm{U} / \mathrm{ml}$ ); and $1.9 \mathrm{ml}$ of distilled water. For C. pylori and St 1 , the reaction was initiated by the addition of $20 \mu \mathrm{l}$ of a bacterial suspension. Comparatively, the rate of urea hydrolysis by $P$. vulgaris was so low that a $1 \cdot 0-\mathrm{ml}$ suspension of this organism had to be added to the reaction mixture. Oxidation of NADH was read at a wavelength of $340 \mathrm{~nm}$ with a distilled water blank, at $35 \pm 1^{\circ} \mathrm{C}$, in a Pye Unicam SP 1800 double beam spectrophotometer (Unicam Instruments Ltd, Cambridge). The reaction was recorded on a Pye Unicam AR25 linear change recorder calibrated to read in the 0
2 optical density range at a chart speed of $1 \mathrm{~cm} / \mathrm{min}$, and the reaction rates were determined. A minimum of eight assays/medium/passage (where appropriate)/strain were done with pooled cells from 2-5 plates. Each culture was tested on at least three separate occasions. All data were included in the calculation of means and $95 \%$ confidence intervals and were compared by a one-way analysis of variance, determined with the STATCALC programme (Lee, McInerney and Mullins, Auckland, New Zealand) on an Apple IIe computer.

Controls were reaction mixture minus urea, and reaction mixture minus bacteria. The concentration of bacterial protein was determined for each cell suspension, and the rate of urea hydrolysis calculated as the rate of urea hydrolysed $/ \mathrm{min} / \mathrm{mg}$ of bacterial protein.

\section{Glutamate dehydrogenase determination}

This was modified from the method of Smith et al. (1981). Bacteria were washed twice in cold $\left(4^{\circ} \mathrm{C}\right) \mathrm{KCl} 1 \%$ $\mathrm{w} / \mathrm{v}$. The resuspended cells were sonicated with a Sonifier Model B-30 Cell Disruptor (Branson Sonic Power Co., Danbury, CT, USA) at $14 \mathrm{kHz}$ for $1 \mathrm{~min} / \mathrm{ml}$ of washed cells. The sonicate was centrifuged at $10000 \mathrm{~g}$ for $5 \mathrm{~min}$ to remove the cell debris and the supernate was stored at $4^{\circ} \mathrm{C}$ until assayed.

A test solution consisting of $\mathrm{NH}_{4} \mathrm{Cl} 32 \mathrm{mg}$, 2oxoglutarate $2.2 \mathrm{mg}$, NADH or NADPH $0.2 \mathrm{mg}$, and $\mathrm{KCl} 6.5 \mathrm{mg}$ was prepared in $1 \mathrm{ml}$ of triethanolamine- $\mathrm{HCl}$

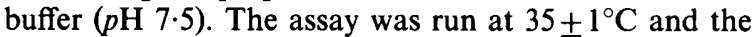
oxidation of NADH or NADPH was read at a wavelength of $340 \mathrm{~nm}$. The reaction was initiated by adding $1 \mathrm{ml}$ of crude bacterial extract to $2 \mathrm{ml}$ of test solution in the spectrophotometer. The rate of NADH or NADPH oxidation in a control solution (the test solution without $\mathrm{NH}_{4} \mathrm{Cl}$ ) was subtracted from that initiated by the bacterial extract. The rate of $\mathrm{NH}_{4}{ }^{+}$utilisation was calculated in terms of $\mu \mathrm{g}$ of $\mathrm{NH}_{4}{ }^{+}$consumed/h/mg of bacterial protein extract.

\section{Protein determination}

Protein estimations were made with the BCA protein assay reagent (Pierce Chemical Co., IL, USA). Bovine serum albumin was the protein standard.

\section{Preparation of samples for SDS-PAGE}

The cells were harvested from the blood-agar plates and washed twice in distilled water, at $4^{\circ} \mathrm{C}$. After resuspending the pellet in a small volume of solubilisation buffer, the cells were sonicated at $8 \mathrm{kHz}, 50 \%$ cycle for 1 min. The solubilisation buffer contained $0.625 \mathrm{M}$ Tris$\mathrm{HCl}(p \mathrm{H} \mathrm{6.8)}$, sodium dodecylsulphate (SDS) $3 \% \mathrm{w} / \mathrm{v}, 2-$ mercaptoethanol $5 \% \mathrm{w} / \mathrm{v}$, glycerol $10 \% \mathrm{v} / \mathrm{v}$ and bromophenol blue $0.01 \% \mathrm{w} / \mathrm{v}$. Cell debris was removed from the sonicate by centrifugation at $13000 \mathrm{~g}$ and the cellfree extract was stored in small volumes at $-20^{\circ} \mathrm{C}$. 
Sodium dodecylsulphate-polyacrylamide gel electrophoresis ( $S D S-P A G E$ )

Extracts containing urease were analysed by SDSPAGE (Laemmli, 1970) in a modification of the method of Senior $e t$ al. (1980). The cell-free extracts were applied to a slab gel comprising a stacking gel of acrylamide $4.5 \%$ $\mathrm{w} / \mathrm{v}$ and a resolving gel of acrylamide either 5 or $6 \% \mathrm{w} / \mathrm{v}$. The samples were stacked at $10 \mathrm{~mA}$ and separated at 20 $\mathrm{mA}$ constant current. The gels were then washed in several changes of a filtered solution of disodium ethylenediaminetetraacetic acid (EDTA) $0.1 \% \mathrm{w} / \mathrm{v}$ and cresol red indicator $0.02 \% \mathrm{w} / \mathrm{v}$ until the gel turned yellow, indicating neutral or slightly acidic conditions. Gels were developed by discarding the washing solution and immersing them in a small volume of urea $1.5 \% \mathrm{w} / \mathrm{v}$. Areas of urease activity appeared as cherry-red bands against the yellow background due to the local production of alkali as a result of enzymic degradation of urea.

The developed gels could be kept conveniently as a permanent record by attaching the gel (through capillary action) to a piece of white paper, which was then photocopied.

\section{Isolation of crude urease}

To isolate urease, a $1.5 \mathrm{~mm}$-thick gel was loaded with only one type of whole-cell extract and run as described above. Once developed, the bands of urease activity were cut from the gel and placed in $0.1 \mathrm{M}$ sodium phosphate buffer $(p \mathrm{H} 7.0)$ containing $0.01 \mathrm{M}$ disodium EDTA and $0.01 \mathrm{M} 2$-mercaptoethanol (stabilisation buffer). The gel slices were macerated with a tissue homogeniser and the preparations were concentrated with Amicon CF25 centriflo ultrafiltration membrane cones (Amicon, Danvers, USA), centrifuged at $850 \mathrm{~g}$ for $10 \mathrm{~min}$ at $4^{\circ} \mathrm{C}$. The retentate was removed from the cones with $0.2 \mathrm{ml}$ of fresh stabilisation buffer and stored in small volumes at $-20^{\circ} \mathrm{C}$.

\section{Western blotting}

Both the whole-cell extracts of bacteria and the crude urease preparations were run on SDS-polyacrylamide gels and then transferred electrophoretically to nitrocellulose paper by the method of Towbin et al. (1979). The transfer step was done in a Trans-Blot Electrophoretic Transfer Cell (Bio-rad, Richmond, CA, USA) for $4 \mathrm{~h}$ at $70 \mathrm{~V}$ with cooling.

The nitrocellulose membrane was blocked with casein $5 \% \mathrm{w} / \mathrm{v}$ in PBS at room temperature, for $2 \mathrm{~h}$. Human sera from diagnosed cases of $C$. pylori-associated gastritis were diluted 1 in 100 in casein $1 \% \mathrm{w} / \mathrm{v}$ in PBS and allowed to react at $4{ }^{\circ} \mathrm{C}$ overnight. All preparations were agitated constantly on a platform shaker. The membrane was washed three times for 5 min each time with Tween $200.05 \% \mathrm{v} / \mathrm{v}$ in PBS, then once with PBS. The membrane was incubated in a solution of biotin-anti-human (total) immunoglobulin (Kirkegaard and Perry Lab., Inc., MD, USA) diluted 1 in 1000 in casein $1 \%$ w/v in PBS at room temperature for $1 \mathrm{~h}$. After washing as described above, the nitrocellulose was allowed to react with avidinperoxidase (KPL) diluted 1 in 2000 in casein $1 \%$ w/v in PBS for a further hour. The membrane was washed and the bound protein detected by adding a substrate solution containing 4-chloro-1-naphthol $0 \cdot 3 \% \mathrm{w} / \mathrm{v}$. The reaction was terminated by bathing the nitrocellulose in distilled water.

\section{Results}

\section{Urease activity}

Preliminary investigations with C.pylori (NCTC $11639)$ revealed that its urease activity was elevated up to two and a half times in cultures incubated for $96 \pm 2 \mathrm{~h}$ compared with cultures incubated for $72 \pm$ $2 \mathrm{~h}$, whether it was grown on lysed horse-blood agar or lysed horse-blood agar containing ammonium chloride $0.2 \% \mathrm{w} / \mathrm{v}$. However, those cultures incubated for $120 \pm 2 \mathrm{~h}$ showed a dramatic decrease in urease activity, probably as a result of cell death and autolysis. Despite the relatively lower urease activity of the 72-h cultures compared with the 96-h cultures, the shorter incubation period was chosen for the remainder of the investigation because the margin between viable and non-viable cells could not be judged easily in the older cultures. Similarly, cultures of $P$. vulgaris were harvested well in advance of the late stationary phase (i.e., after $18 \mathrm{~h})$.

The urease activities of washed cells of C. pylori, the rodent spiral bacterium, St1, and $P$. vulgaris were compared (fig. 1). The urease activities of the C. pylori strains were in the range $200-700 \mu \mathrm{g}$ of urea hydrolysed $/ \mathrm{min} / \mathrm{mg}$ of bacterial protein. There was no significant difference $(p>0.05)$ between the urease activities of Stl and C. pylori NCTC 11639. Moreover, strain NCTC 11639 exhibited an activity which was, within one order of magnitude, similar to that of the two freshly isolated strains of $C$. pylori, 5298 and P2. Conversely, P. vulgaris, an archetypal ureolytic bacterium, exhibited a markedly lower urease activity of $9 \cdot 4-10 \cdot 6 \mu \mathrm{g}$ of urea hydrolysed $/ \mathrm{min} / \mathrm{mg}$ of bacterial protein.

To test the effect of ammonia on the urease of $C$. pylori, ammonium chloride $0.2 \% \mathrm{w} / \mathrm{v}$ was added to the lysed-blood media (fig. 1). The two fresh clinical isolates exhibited an initial depression in urease activity when plated on to the ammonium-enriched medium but this was neither significant nor, in the case of the one strain tested further, sustained. Strain NCTC 11639 did not show this initial depression of urease activity. The results suggested that urease is a constitutive enzyme in C.pylori and 


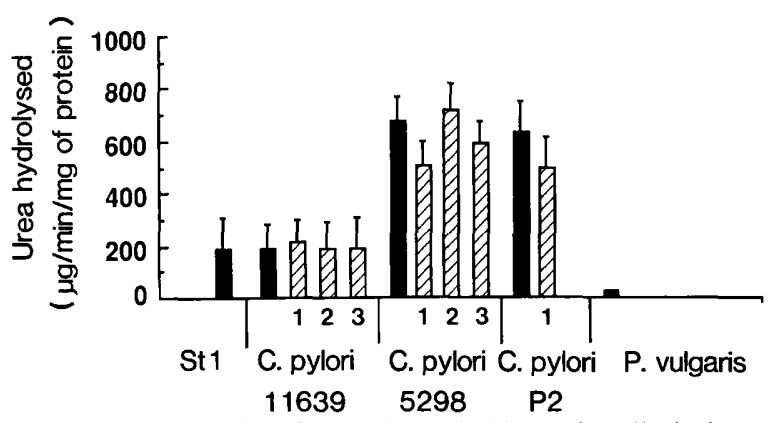

Fig. 1. Urease activity of the rodent spiral bacterium (St1), three strains of $C$. pylori and $P$. vulgaris after growth on lysed-horseblood agar ( $\square$ ). Columns 1,2 and 3 indicate the activities of cultures passaged 1,2 and 3 times respectively, on medium supplemented with $\mathrm{NH}_{4} \mathrm{Cl} 0 \cdot 2 \% \mathrm{w} / \mathrm{v}(\square)$. The results represent the mean activity with $95 \%$ confidence intervals.

Stl. Furthermore, the level of urease activity of $C$. pylori is independent of either the effects of a rich nitrogen source, or the presence of ammonia.

\section{Glutamate dehydrogenase activity}

Three fresh isolates (strains P16, P17 and P21) of C. pylori were tested and found to have NADPHdependent glutamate dehydrogenase (GDH) activities of $28-84 \mu \mathrm{g}$ of ammonia consumed $/ \mathrm{h} / \mathrm{mg}$ of bacterial protein. Stl expressed an NADPHdependent GDH activity of $15 \mu \mathrm{g}$ ammonia consumed $/ \mathrm{h} / \mathrm{mg}$ of bacterial protein. This indicated that $C$. pylori and St1 have the ability to assimilate ammonia and may use the ammonia released during ureolysis to synthesise important amino acids.

\section{Identification of urease by $S D S-P A G E$}

The urease enzymes of $C$. pylori and Stl retain their enzymic activity on SDS-polyacrylamide gels, thus simplifying enzyme identification and isolation. Fig. $2 \mathrm{a}$ is a photocopy of a gel on which wholecell extracts of Stl and five strains of C. pylori were run. The banded areas represent zones of intense red colouration where the $p \mathrm{H}$ of the gel has changed due to the hydrolysis of urea at that site. All six strains of $C$. pylori tested had a $300000-\mathrm{mol} . w \mathrm{t}$ major active subunit. Occasionally a band of higher mol.wt appeared but this was not restricted to any one strain or preparation, nor was it a consistent finding. This phenomenon was thought to be due to an aggregation of the urease molecule, possibly with a non-active subunit. In contrast, ST1 had two major subunits of mol. wts 140000 and 150000 .

\section{Anti-urease antibodies}

Western blot analysis of a crude urease preparation from $C$. pylori NCTC 11639 with human $C$. pylori antiserum is presented in fig. $2 \mathrm{~b}$. The recognition of two proteins at mol.wt c. 300000 correspond to the major subunit of $C$. pylori urease described above. These results suggested that the complete urease enzyme may exist in a dimeric form, but whether both molecules are enzymically active is not known. The protein of mol.wt 120000 is probably a degradation product or a non-catalytic isoenzyme (Fishbein et al., 1969; Delisle, 1977).

The urease enzymes from three strains of $C$. pylori were isolated and the responses to these with three samples of human anti- $C$. pylori serum (collected as part of another study) were tested. It was highly unlikely that any of the sera could have been from persons infected with a strain of $C$. pylori that was homologous to those used for the enzyme isolation, yet each of the three sera reacted with the urease enzymes of one or more of the $C$. pylori strains. Thus the $300000-$ and $120000-\mathrm{mol}$.wt proteins of $C$. pylori were not strain specific, nor were they recognised by rabbit antiserum raised against saline-washed whole cells of Stl although this antiserum reacted with both Stl gel bands. Similarly, anti- $C$. pylori human antisera did not react with a crude preparation of St 1 urease.

\section{Discussion}

Although there has been much speculation about the role of the urease of $C$. pylori (Goodwin et al., 1986; Hazell and Lee, 1986; Rathbone et al., 1986), no detailed work on the enzyme has been published until now. $C$. pylori is a member of a large group of spiral bacteria which associate with the mucus lining the mammalian gastrointestinal tract. Another spiral bacterium, St1, isolated from the ileal crypts of rodents by workers in our laboratory (Lee and Phillips, 1978) shares several properties with C. pylori. Both bacteria are micro-aerophilic, have multiple sheathed flagella, have adapted to a mucus environment, and possess an extremely high level of urease activity. C. pylori and Stl preferentially colonise different areas of the gastrointestinal tract; we postulate that these micro-organisms have adapted to their particular niches by developing characteristics that give them a selective advantage in the colonisation of the mucus that lines the gastrointestinal tract and that urease is an important colonisation factor for both bacteria.

Savage (1983) suggested that urea may be a valuable nutrient for organisms colonising the 


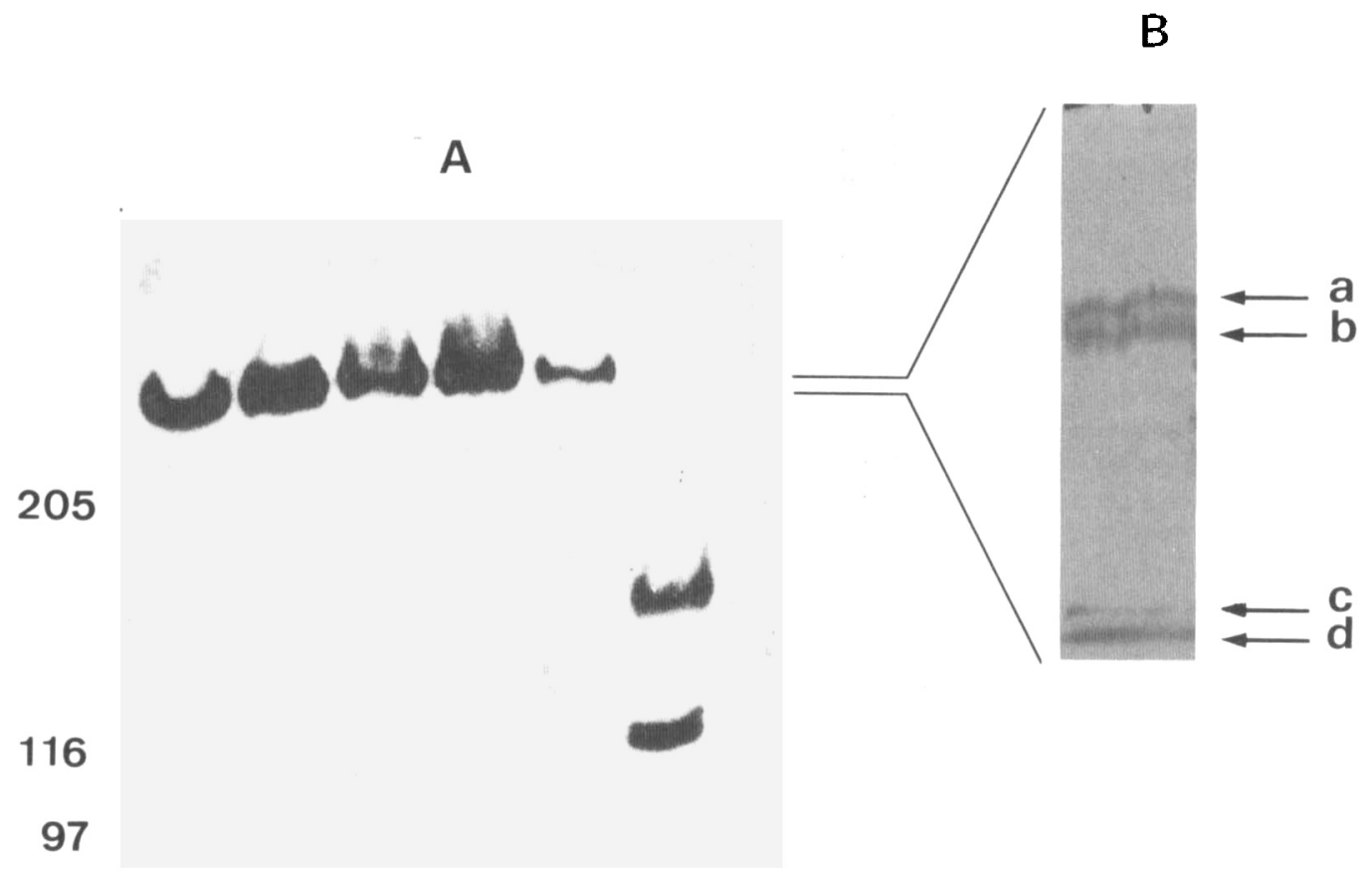

\section{$\begin{array}{llllll}1 & 2 & 3 & 4 & 5 & 6\end{array}$}

Fig. 2. (a) SDS-PAGE of whole-cell extracts of Stl and five $C$. pylori strains on a resolving gel of acrylamide $6 \%$ w/v. The bands correspond to areas of urease activity. Samples were from (lanes): 1, C. pylori strain D1; 2, C. pylori NCTC 11639; 3, C. pylori P21; 4, C. pylori $\mathrm{G} 1 ; 5$, C. pylori $\mathrm{P} 3 ; 6$, Stl. The numbers on the left indicate mol. wts $10^{3}$. C. pylori urease was extracted from a gel, subjected to SDS-PAGE and transferred to nitrocellulose paper. (b) The electroblotted proteins from a crude urease preparation were allowed to react with human serum from a case of $C$. pylori-associated gastritis. Bands labelled a and b represent two urease subunits of mol. wt c. 300000 . Band c represents a $120000-\mathrm{mol}$. wt. protein and label d indicates the level of the protein front.

mucosal surfaces of the gut. Evidence for this suggestion is the consistent finding of bacterial urease activity in the stomach and rumen of animals (Fitzgerald and Murphy, 1950; Von Korff and Glick, 1951; Von Korff et al., 1951; Kornberg et al., 1954a,b; Wallace et al., 1979). Hazell et al. (1986) described the localisation of $C$. pylori on the human gastric mucosa close to the intercellular junctions. Nutrients diffusing across the mucosa via the paracellular route would thus be readily available to the organism; one such solute is urea which primarily traverses the mucosa by this pathway (Powell, 1981). Urea is an available nitrogen source that represents up to $50 \%$ or more of the non-protein nitrogen of human serum.

The prime function of urease in many species of bacteria is to supply urea nitrogen to cells in a form that can be assimilated. Ammonia, a product of urea hydrolysis, has been shown to indirectly repress the urease activity of Selenomonas ruminantium and Klebsiella aerogenes (Friedrich and Magasanik,
1977; Smith et al., 1981). In some species of bacteria, urease can only be detected following nitrogen starvation (Kaltwasser et al., 1972) whereas others (e.g., P. vulgaris and Sporosarcina ureae) are unaffected by the external ammonia concentration, and appear to synthesise urease constitutively (Friedrich and Magasanik, 1977).

The urease activity of $C$. pylori does not require nitrogen starvation for detection and is not repressed by an elevated concentration of ammonium ions (fig. 1); therefore the enzyme in this species is constitutive. The finding of a lower level of urease activity in strain NCTC 11639 , compared with that of the two freshly isolated strains, may be due to the number of subcultures that it had undergone, both before and after its arrival at our laboratory, or may reflect a true variation within the species.

Kaltwasser et al. (1972) suggested that as long as the product of urea hydrolysis did not accumulate, repression of urease may not occur. Utilisation of ammonia is accomplished via glutamate dehydro- 
genase (GDH) or glutamine synthetase (GS), the former operating in environments rich in ammonia (Kleiner et al., 1981). The gastrointestinal tract has a high concentration of ammonia, thus GDH would be the most important ammonia-assimilating enzyme in such an environment (Hespell and Smith, 1983). Both C. pylori and the rat ileal isolate Stl possess an NADPH-dependent GDH and would be able to assimilate the large amounts of ammonia, released during urea hydrolysis, for the synthesis of glutamate from $\alpha$-ketoglutarate. These substances are the preferred metabolites for transaminase reactions, which play an important role in the degradation and synthesis of amino acids. Therefore, an important function of urease in these bacteria may be the supply of urea nitrogen, in the form of ammonia, to the cell.

Ammonia is the most abundant nitrogen compound in the rumen and arises from the breakdown of dietary proteins or urea. Most ruminal bacteria are able to use ammonia as their sole source of nitrogen and, generally, do not require amino acids for growth (Hespell and Smith, 1983). Similarly, major species isolated from the human colon have a preference for ammonia (Bryant, 1974). Many of these bacteria produce urease, the activity of which is regulated by the availability of nitrogen for growth.

C. pylori is more fastidious in its growth requirements than either the ruminal or colonic bacteria. The gastric campylobacter grows on enriched media containing complex organic constituents such as blood, peptones and yeast extract. $C$. pylori seems to depend upon nitrogen compounds, particularly amino acids, for its growth.

If, as we assert, $C$. pylori utilises ammonia released during ureolysis for the de novo synthesis of amino acids, why should the organism also require the uptake of amino acids for growth? The low affinity of GDH for $\mathrm{NH}_{4}^{+}$(Smith et al., 1981) and the large quantities of ammonia liberated by the urease enzyme suggest that it is unlikely that all of the ammonia could be utilised for the synthesis of amino acids. Moreover it would be metabolically inefficient to do so as amino acids and peptides are freely available in the stomach as a result of the digestion of dietary protein. The nutritional requirement of $C$. pylori for particular amino acids may be necessary for the conversion to other metabolically useful substrates.

A salient observation is that $C$. pylori can grow on media which is essentially free of carbohydrates. McNulty and Dent (1987) tested between 25 and 129 isolates of $C$. pylori for each sugar commonly used in sugar fermentation tests and found that none of the isolates were able to metabolise sugars. The rodent isolate $\mathrm{St} 1$ has a similar requirement for nitrogen compounds and also cannot metabolise sugars (Phillips and Lee, 1983). The inability to oxidise or ferment sugars is a character shared by all members of the genus Campylobacter and most of the bacteria assigned to the aerobic or microaerophilic, motile, helical or vibrioid gram-negative taxa described in Bergey's Manual of systematic bacteriology (1984). How C.pylori derives its carbon and energy needs is not known. It is possible that this organism fulfills these needs by the metabolism of nitrogen compounds via TCA cycle intermediates, conversion of amino acids or uptake of the carbon dioxide released during ureolysis.

Goodwin et al. (1986) suggested that the prime function of the urease of $C$. pylori is the defence of the organism against acid damage, by surrounding the bacterium with an alkaline cloud. If the urease activity of $C$. pylori plays any role in the defence of the bacterium against acid, it is important to consider whether this is a primary or secondary function.

C. pylori is generally found in close proximity to the epithelial cells or within the gastric mucus; the former is an essentially neutral environment and the latter a component of a system which limits acid diffusion (Williams and Turnberg, 1980, 1981; Smith et al., 1985). Furthermore, the spiral bacterium Stl has a level of urease activity similar to that of the gastric campylobacter (fig. 1), and yet preferentially colonises the non-acid-secreting mucosae of the rodent ileum. It seems unlikely that an organism would devote a significant proportion of its anabolic activity to the synthesis of an enzyme that depends on an external supply of substrate as a protective mechanism useful only transiently while the bacterium passes from the gastric lumen into the mucus layer. A more logical strategy would be the development of acid tolerance, as seen with the lactobacilli present in the acid environments of the mouse stomach and the human vagina.

Rather, as previously suggested (Hazell and Lee, 1986), the rapid hydrolysis of urea by $C$. pylori localised at the gastric intercellular junctions would induce a net flux of urea across the mucosa, thus maintaining a near constant supply of urea nitrogen. Because of the effect this constant urea hydrolysis would have on the local $p \mathrm{H}$, the bacterium would become adapted to an alkaline environment, thus rendering $C$. pylori to some degree acid-sensitive. In this circumstance, the presence of ammonia may, as a secondary consequence, confer some protection from gastric acidity. Whereas we do not consider the function of urease to be primarily an 
acid-protective mechanism, the extremely high level of activity of this enzyme appears to be greater than would be needed if its sole purpose was to capture urea nitrogen. Thus the change in environment caused by the breakdown of urea to ammonia (and carbon dioxide) is likely to be of further benefit to the organism. The nature of this further ecological advantage provided by the enzyme is unknown.

Investigation of the role of urease as a colonisation factor for $C$. pylori and Stl requires the identification and characterisation of the enzymes from these two bacteria. Thus the proteins in wholecell extracts of $C$. pylori and St 1 were separated by SDS-PAGE and the urease enzymes, which retained their activity on SDS-polyacrylamide gels, were identified. In the reducing, denaturing conditions used in our method, a catalytically-active band of mol. wt 300000 was isolated from all strains of $C$. pylori tested (fig. 2a). This was thought to be a subunit of the complete enzyme structure. The urease profile of $\mathrm{Stl}$ differed appreciably from that

\section{REFERENCES}

Bergey's Manual of systematic bacteriology, 9th edn 1984 Krieg N R, Holt J G (eds), Williams and Wilkins, Baltimore.

Braude A I, Siemienski J 1960 Role of bacterial urease in experimental pyelonephritis. Journal of Bacteriology $\mathbf{8 0}$ : $171-179$.

Bryant M P 1974 Nutritional features and ecology of predominant anaerobic bacteria of the gastrointestinal tract. American Journal of Clinical Nutrition 27: 1313-1319.

Cheng K J, Wallace R J 1979 The mechanism of passage of endogenous urea through the rumen wall and the role of ureolytic epithelial bacteria in the urea flux. British Journal of Nutrition 42: 553-557.

Delisie G J 1977 Multiple forms of urease in cytoplasmic fractions of Ureaplasma urealyticum. Journal of Bacteriology 130: $1390-1392$.

Fishbein W N, Spears C L, Scurzi W 1969 Spectrum of urease isozymes: genetic, polymeric and conformeric. Nature 223: 191-193.

Fitzgerald O F, Murphy P M 1950 Studies on the physiological chemistry and clinical significance of urease and urea with special reference to the stomach. Irish Journal of Medical Science 292: 97-159.

Friedrich B, Magasanik B 1977 Urease of Klebsiella aerogenes: control of its synthesis by glutamine synthetase. Journal of Bacteriology 131 : 446-452.

Goodwin C S, Armstrong J A, Marshall B J 1986 Campylobacter pyloridis, gastritis, and peptic ulceration. Journal of Clinical Pathology 39: 353-365.

Griffith D P, Musher D M 1973 Prevention of infected urinary stones by urease inhibition. Investigative Urology 11 : 228233.

Hazell S L, Lee A 1986 Campylobacter pyloridis, urease, hydrogen ion back diffusion, and gastric ulcers. Lancet 2: 15-17.

Hazell S L, Lee A, Brady L, Hennessy W 1986 Campylobacter pyloridis and gastritis: association with intercellular spaces and adaptation to an environment of mucus as important of $C$. pylori with two subunits present at mol. wts 140000 and 150000 . Different urease profiles do not discount the possibility that the two organisms are closely related, given that even within the genus Proteus there is diversity in isoenzyme patterns (Senior et al., 1980).

Regardless of whether the urease of $C$. pylori plays a role in the pathogenesis of gastric ulcer, is required for the nutrition of the organism, or is protective against acid, one would expect antibodies to be produced against the enzyme. Such antibodies were found in diagnosed cases of $C$. pylori-associated gastritis. Demonstration of a homogeneous urease molecule in $C$. pylori strains, which is not strain-specific and which does not cross-react with that of a closely related bacterium, may be of practical value in the diagnosis of $C$. pylori-associated gastritis by immunoassay.

This work was supported by the National Health and Medical Research Council of Australia. factors in colonization of the gastric epithelium. Journal of Infectious Diseases 153: 658-663.

Hazell S L, Borody T J, Gal A, Lee A 1987 Campylobacter pyloridis gastritis $\mathrm{I}$ : Detection of urease as a marker of bacterial colonization and gastritis. American Journal of Gastroenterology 82 : 292-296.

Hespell R B, Smith C J 1983 Utilization of nitrogen sources by gastrointestinal tract bacteria. In: Hentges D J (ed) Human intestinal microflora in health and disease. Academic Press, New York, p 167.

Kaltwasser H K, Schlegel H G S 1966 NADH-dependent coupled enzyme assay for urease and other ammoniaproducing systems. Analytical Biochemistry 16: 132-138.

Kaltwasser H, Krämer J, Conger W R 1972 Control of urease formation in certain aerobic bacteria. Archiv für Mikrobiologie 81 : 178-196.

Kleiner D, Phillips S, Fitzke E 1981 Pathways and regulation aspects of nitrogen and ammonium assimilation and nitrogen-fixing bacteria. In: Bothe $H$, Trebst A (eds) Biology of inorganic nitrogen and sulphur metabolism. Springer, New York, pp 131-140.

Kornberg H L, Davies R E, Wood D R 1954a The breakdown of urea in cats not secreting gastric juice. Biochemistry Journal 56: 355-363.

Kornberg H L, Davies R E, Wood D R $1954 b$ The activity and function of gastric urease in the cat. Biochemistry Journal 56: $363-372$.

Laemmli U K 1970 Cleavage of structural proteins during the assembly of the head of bacteriophage T4. Nature 227:680685 .

Lee A, Phillips M 1978 Isolation and cultivation of spirochaetes and other spiral-shaped bacteria associated with the cecal mucosa of rats and mice. Applied and Environmental Microbiology 35: 610-613.

Marshall B J, Warren J R 1984 Unidentified curved bacilli in the stomach of patients with gastritis and peptic ulceration. Lancet 1: 1311-1314.

McNulty C A M, Dent J C 1987 Rapid identification of 
Campylobacter pylori ( $C$. pyloridis) by preformed enzymes. Journal of Clinical Microbiology 25: 1683-1686.

McNulty C A M, Watson D M 1984 Spiral bacteria of the gastric antrum. Lancet 1 : 1068-1069.

McNulty C A M, Wise R 1985 Rapid diagnosis of Campylobacterassociated gastritis. Lancet 1 : 1443-1444.

Musher D M, Griffith D P, Yawn D, Rossen R D 1975 Role of urease in pyelonephritis resulting from urinary tract infection with Proteus. Journal of Infectious Diseases 131 : 177-181.

Phillips M W, Lee A 1983 Isolation and characterization of a spiral bacterium from the crypts of rodent gastrointestinal tracts. Applied and Environmental Microbiology 45: 675-683.

Powell D W 1981 Barrier function of epithelia. American Journal of Physiology 241 : G275-288.

Rathbone B J, Wyatt J I, Heatley R V 1986 Campylobacter pyloridis-a new factor in peptic ulcer disease? Gut 27 : 635641.

Rollason T P, Stone J, Rhodes J M 1984 Spiral organisms in endoscopic biopsies of the human stomach. Journal of Clinical Pathology 37: 23-26.

Savage D C 1983 Mechanisms by which indigenous microorganisms colonize gastrointestinal epithelial surfaces. Progress in Food Nutrition Science 7: 65-74.

Senior B W, Bradford N C, Simpson D S 1980 The ureases of Proteus strains in relation to virulence for the urinary tract. Journal of Medical Microbiology 13: 507-512.

Smith C J, Hespell R B, Bryant M P 1981 Regulation of urease and ammonia assimilatory erizymes in Selenomonas ruminantium. Applied and Environmental Microbiology 42: 89-96.
Smith G W, Tasman-Jones C, Wiggins P M, Lee S P 1985 Pig gastric mucus: a one-way barrier for $\mathrm{H}^{+}$. Gastroenterology 89: 1313-1318.

Sumner J B 1926 The isolation and crystallization of the enzyme urease. Journal of Biological Chemistry 69 : 435-441.

Towbin H, Staehelin T, Gordon J 1979 Electrophoretic transfer of proteins from polyacrylamide gels to nitrocellulose sheets: procedure and some applications. Proceedings of the National Academy of Sciences of the USA 76: 4350-4354.

Von Korff R W, Glick D 1951 Role of urease in the gastric mucosa. II: In vitro studies with isotopic urea on frog mucosa. American Journal of Physiology 165: 688-694.

Von Korff R W, Ferguson D J, Glick D 1951 Role of urease in the gastric mucosa. III. Plasma urea as source of ammonium ion in gastric juice of histamine-stimulated dog. American Journal of Physiology 165: 695-700.

Wallace R J, Cheng K J, Dinsdale D, Orskov E R 1979 An independent microbial flora of the epithelium and its role in the ecomicrobiology of the rumen. Nature 279: 424-426.

Williams S E, Turnberg L A 1980 Retardation of acid diffusion by pig gastric mucus: a potential role in mucosal protection. Gastroenterology 79: 299-304.

Williams S E, Turnberg L A 1981 Demonstration of a $p H$ gradient across mucus adherent to rabbit gastric mucosa: evidence of a "mucus-bicarbonate" barrier. Gut 22: 94-96.

Wozny M A, Bryant M P, Holdeman L V, Moore W E C 1977 Urease assay and urease-producing species of anaerobes in the bovine rumen and human feces. Applied and Environmental Microbiology 33: 1097-1104. 